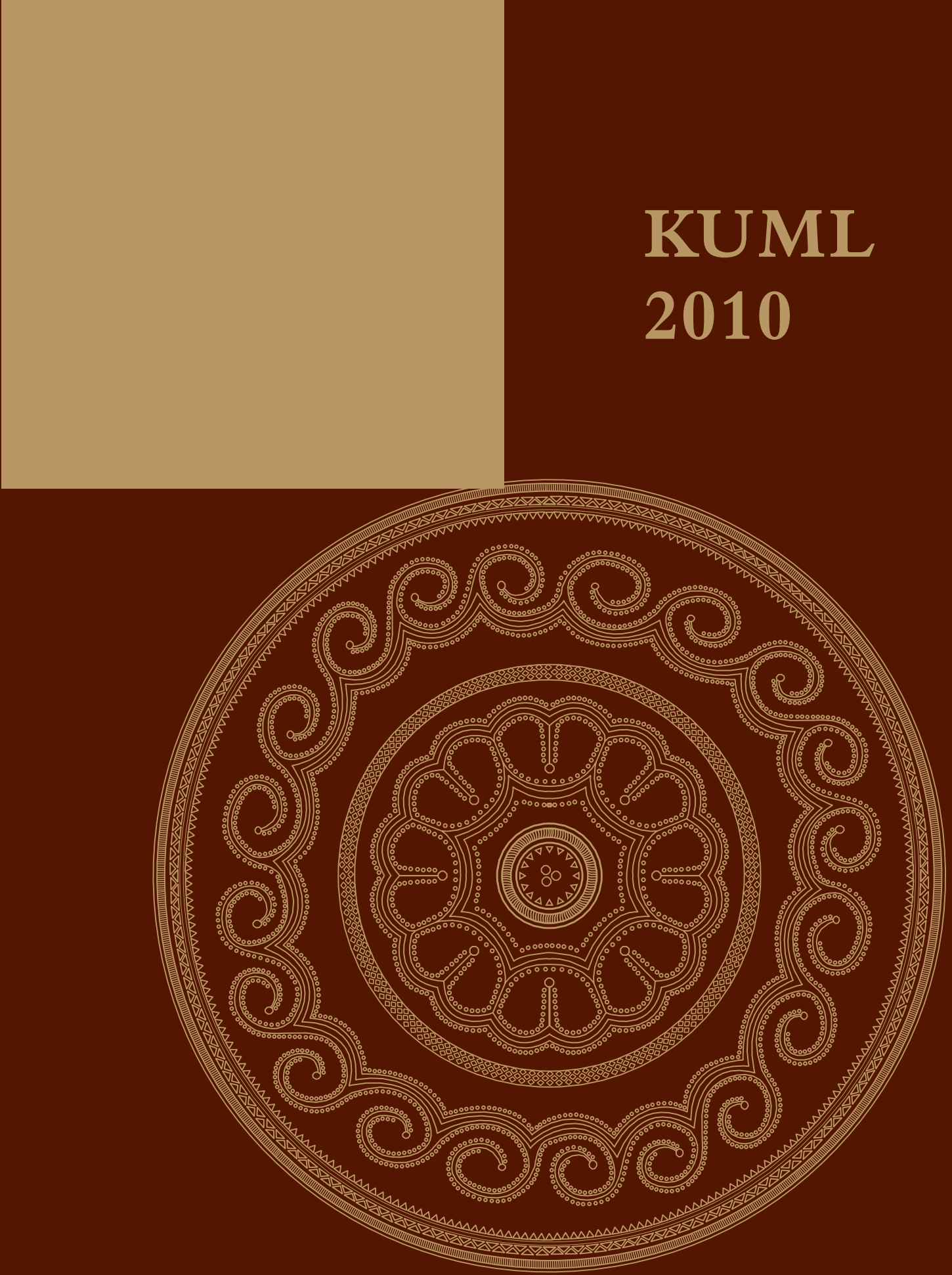




\section{KUML 2010}

Årbog for Jysk Arkæologisk Selskab

With summaries in English

I kommission hos Aarhus Universitetsforlag 


\title{
Nybyggede fortidsminder
}

\author{
Af PALLE ERIKSEN \& NIELS H. ANDERSEN
}

Et par kilometer øst for Toreby på Lolland ligger jættestuen Barneshøj. Modsat nogle af øens andre jættestuer, hvor den mest fremtrædende er den imponerende Kong Svends Høj, er Barneshøj ikke specielt imponerende. Jættestuen var allerede i 1800-tallet svært molesteret, dens høj var gravet væk, og flere bære- og dæksten var fjernet fra kammer og gang. Så da Barneshøj omsider blev fredet ved tinglysning i 1954, var kun det halve af kammeret tilbage med $i$ alt syv bæresten og en dæksten.

I lidt over et halvt hundrede år lå jættestueruinen som et uantastet vidnesbyrd om, at mange store stengrave tidligere blev ødelagt, da de store sten kunne gøre nytte andetsteds. Men så skete der noget i 2008. Barneshøj blev erklæret for livsfarlig, idet man skønnede, at dækstenen kunne skride ned. Derfor besluttede Nationalmuseet, som dengang havde ansvaret for restaureringen af de store stengrave, at afmontere dækstenen. Det blev gjort ved hjælp af en kran, og på en ret så klodset måde, for da dækstenen blev løftet af, væltede bærestenene om, kun 2-3 stykker blev mere eller mindre stående.

Et sådant indgreb vakte selvfølgelig opsigt lokalt og foranledigede Sven Thorsen, der bor i nærheden, til at fare i blækhuset og skrive en artikel, hvor han råbte vagt i gevær. I artiklen maner han til besindighed i restaureringsarbejdet og henstiller, at restaureringsholdet har en mere ydmyg tilgang til de fredede fortidsminder, bl.a. undlader at anvende nye sten, fylde gamle huller op med jord, lægge rullegræs ud og i øvrigt overholde Venezia-charterets bestemmelser om restaureringsprincipper, som Danmark tilsluttede sig i 1964. Artiklen "Livsfarlige fortidsminder" blev bragt i Kuml 2008. Nu er Sven Thorsen ikke ukendt i arkæologiske kredse, indtil midten af 1980'erne arbejdede han i Miljøministeriet og var ansvarlig for restaureringen af de store stengrave, ligesom han har skrevet flere artikler om disse monumenter.

I Kuml-artiklen, der ledsages af et par fotos af Barneshøj før og efter, at dækstenen blev fjernet, hedder det, "at det bliver spændende at se, om Kulturarvsstyrelsen vil fortsætte "skønhedskurene", eller om man vil vælge at gøre en indsats for at beskytte og bevare de sidste rester af den ægte stenalderarkitektur". Kulturarvsstyrelsen havde nemlig i 2008 opsagt aftalen med 


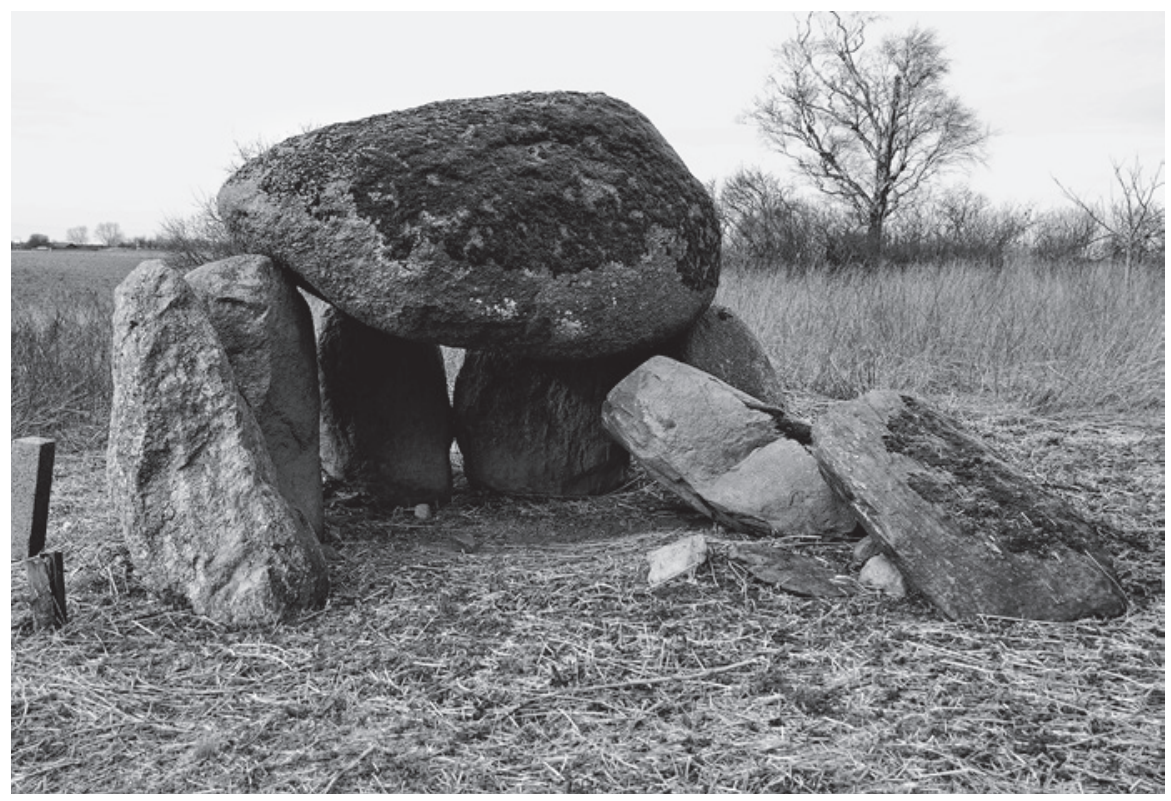

Barneshøj i 2008 før dækstenen blev taget af. - Foto: Jørgen Westphal.

Nationalmuseet, da styrelsen selv fremover ville varetage restaureringsopgaverne.

I samme Kuml 2008 svarede restaureringsholdet ved Torben Dehn, Svend Illum Hansen og Jørgen Westphal i artiklen "Sikre fortidsminder” på Sven Thorsens kritik, som de var meget afvisende overfor. Her skal vi blot hæfte os ved følgende udsagn: "Som bekendt indebærer enhver arkæologisk udgravning en form for destruktion af det oprindelige. Det gælder selvfølgelig også, selv om det oprindelige stenalderanlæg er ødelagt så sent som i 1800-tallet. Derfor foretages restaureringsindgrebene $\mathrm{i}$ de fredede fortidsminder i mindst muligt omfang. ... Oftest arbejdes der i eksisterende plyndringshuller eller udgravningsfelter fra nyere tid, sådan at flest mulige af anlæggets intakte dele lades urørte. ... Rekonstruktioner udføres kun i det omfang, det er påkrævet af hensyn til sikkerhed og holdbarhed".

Det lyder jo meget betryggende. Så umiddelbart skulle man tro, at Barneshøjs væltede bæresten ville blive rejst og dækstenen lagt tilbage, så den lå forsvarligt. Og det ville så være det. Det skete da også i 2009. Men som fotografiet af den nyrestaurerede jæettestue viser, var der sket mere end det. Man havde gravet hele kammeret og gangen ud for at finde standsporene efter de fjernede bæresten. I dem var der så sat halvt overskårne sten op, seks i kam- 


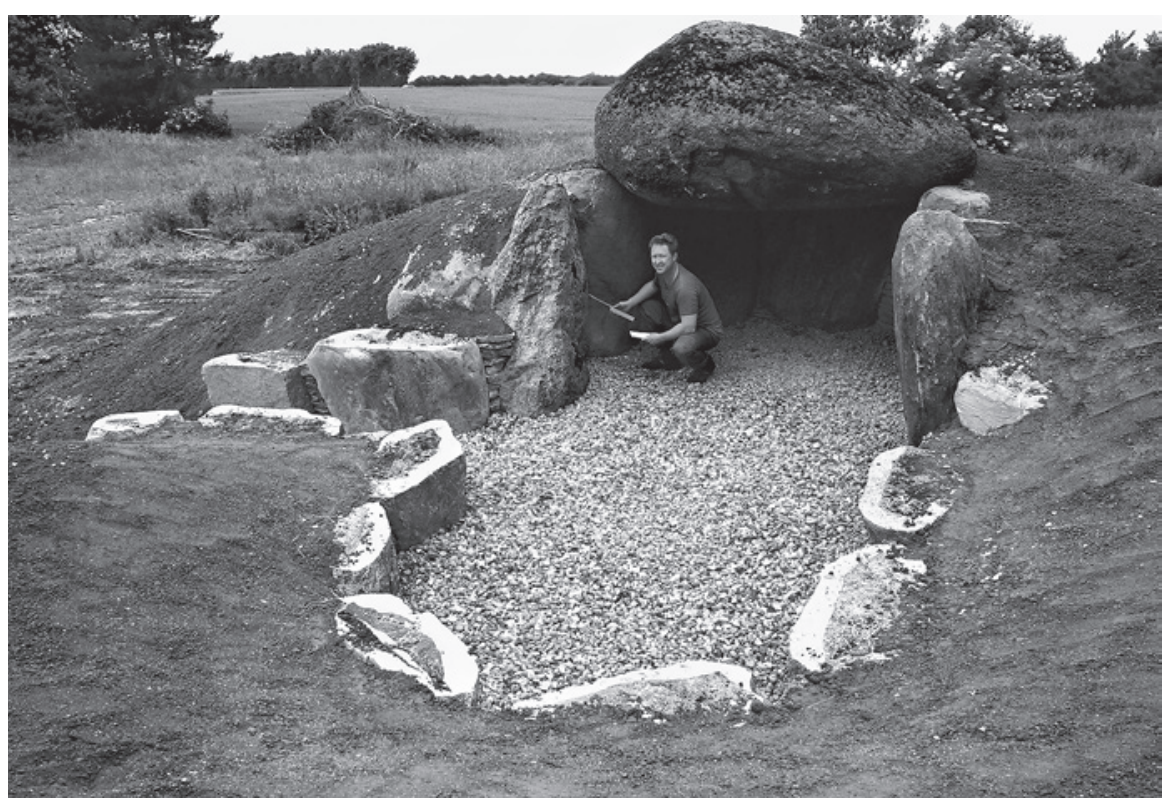

Barneshøj i 2009 efter nybyggeriet. Dækstenen er anbragt forkert, da den er drejet en halv omgang i forhold til dens oprindelige placering. - Foto: Kulturarvsstyrelsen.

meret og fire i gangen. Brug af overskårne sten til dette formål er en nyskabelse i dansk restaurering. Mellemrummene mellem stenene, både de hele og de halve, var tætnet med opstablinger af røde sandstensfliser, såkaldte tørmure, svarende til lignende mure i stenalderen. I bunden af kammer og gang var strøet lyst ral. Op til toppene af de hele og halve bæresten var derefter lagt jord for at holde på stenene.

Denne restaurering, som måske snarere burde kaldes for nybyggeri, er af flere grunde problematisk, og den er i direkte modstrid med restaureringsholdets ovenfor refererede udsagn:

- For at lokalisere standsporene har man forstyrret og fjernet arkæologiske lag og oldsager, som fredningen skulle beskytte.

- Formidlingen af anlægget overskygger totalt restaureringens fornemste og eneste formål: at beskytte og bevare.

- Man har brugt rigtige nye sten, om end overskårne, og sat dem ind på for længst fjernede stens plads.

- Man har lavet tørmure magen til de originale.

- Man har fuldstændigt ændret karakteren og fremtoningen af monumentet, som var præget af tidens tand. 
Nybyggeriet af Barneshøj er ikke et isoleret tilfælde. År efter år tilbage til midt i 1980'erne har restaureringsholdet foretaget nybyggeri på de fredede jættestuer. Indenfor de tre sidste år kan nævnes Mogenstrup ved Nimtofte på Djursland i 2007, Vasagården på Bornholm i 2008 og Thorshøj på Mors i 2009. Gange og kamre graves ud, manglende dxk- og bæresten erstattes med nye sten, huller i højoverflader fyldes ud, membraner lægges over højene, der til sidst forsynes med rullegræs. Ved Mogenstrup og Vasagården blev de nye sten ikke mærket og vil også af kyndige arkæologer blive opfattet som hørende til den oprindelige stenalderarkitektur.

Venezia-charterets artikel 12 er væsentlig for diskussionen om brugen af nye sten ved restaureringen af de store stengrave: "Bygningspartier, som skal erstatte manglende dele, må slutte sig harmonisk til helheden, men dog adskille sig fra de omgivende partier, således at restaureringen ikke forfalsker kunstneriske og historiske vidnesbyrd". (Venezia-charteret - om bevaringsarbejde, 1975, oversat af Harald Langberg).

Sætningen "men dog adskille sig fra de omgivende partier" er afgørende, idet den medfører, at nye partier laves i et andet materiale og/eller har en anden farve, men alligevel på en sådan måde, at de slutter sig harmonisk til helheden.

Når man således laver tørmure med røde sandsten, stort set magen til stenalderens, så er det i modstrid med charterets bestemmelser. Her kunne man i stedet bruge et klart andet materiale som for eksempel grå cementfliser. Så kunne man tydeligt se, hvad der var originalt, og hvad der var nyt.

Også brugen af nye sten som erstatning for fjernede bære- og dæksten samt andre synlige sten i konstruktionen er i modstrid med Venezia-charteret. Før charteret kom til verden i 1964, havde det i Danmark været almindeligt at anvende nye sten, indtil Nationalmuseets konservator, Julius Raklev, i 1948 gik på pension. Han var kendt for sine hårdhændede, kosmetiske restaureringer af især dysser, hvor væltede randsten blev rejst og manglende randsten erstattet med nye. Og manglede et dyssekammer en dæksten, så kunne der også rådes bod på det. Efter Julius Raklevs tid skete en afmatning - heldigt nok - i restaureringsarbejdet, og en ny tid med mere pli overfor de store stengrave indfandt sig. Da Poul Kjærum i 1950'erne undersøgte og restaurerede kulthuset, jættestuen og de to dysser i Tustrup skete det helt uden anvendelse af nye sten. Manglende sten ved sammenløbet af gang og facade til jættestuen blev erstattet af vægge bygget af græstørv. Sven Thorsen benyttede samme teknik i slutningen af 1970'erne ved restaureringen af langdyssen Capeshøj på Tåsinge. Her gjaldt det de manglende randsten. Ved en restaurering i 1980 af indgangspartiet ved Tustrup-jættestuen, hvor Poul Kjærums græstørvsvægge var slidt 
helt ned, blev de erstattet af lodretstillet tømmer. Måske ikke særligt kønt, men helt i overensstemmelse med Venezia-charteret.

Efter midten af 1980'erne ændrede restaureringspraksis sig. Nu blev der igen brugt nye sten som erstatning for ødelagte eller fjernede sten - som en slags post-raklevisme. Og det er en praksis, som er fortsat siden. Tiltaget med de nye sten forsvares ved, at de hver især er mærket med et $8-10 \mathrm{~cm}$ stort, rundt stålemblem, der dog er så diskret anbragt, at det nogle gange slet ikke kan ses. Hvis man da ikke ligefrem har glemt at mærke de nye sten, som tilfældet er ved Vasagården og Mogenstrup.

Men, men ... det er i forhold til Venezia-charteret dybt problematisk med de nye sten, selv når de er forsynet med et stålemblem. Stenene er jo fuldstændig magen til dem, der blev brugt i stenalderen, og ingen, der besøger de nybyggede jættestuer i dag, lægger mærke til, at de er nye. Som fagfolk med særlig kendskab til dysser og jættestuer kan vi ikke acceptere dette nybyggeri, og det er en holdning, som deles af mange arkæologer. Vi holder af de store stengrave, som med deres slid og mangler er overleveret os gennem årtusinder. Skal der absolut fyldes huller ud efter manglende sten, så brug et andet materiale. Det vil måske ikke se kønt ud, men så vil det have den fordel, at kun det nødvendigste bliver restaureret. Og i særlige, alvorlige tilfælde, der vil kræve omfattende og dyr restaurering, kan man jo vælge at tildække de faretruende partier med sand og grus.

Sammenligner man restaureringspraksis ved de store stengrave med metoderne ved restaurering af middelalderlige ruiner eller kalkmalerier, falder dette i forhold til Venezia-charteret ikke ud til fordel for stengravene.

Ved de middelalderlige ruiner genopføres for eksempel ikke fjernede mure i deres oprindelige, fulde højde. I stedet for beskyttes den eksisterende del af toppen - murkronen - af en mere eller mindre nedbrudt mur med et "offerlag" i form af tre skift munkesten, der dækkes med græstørv. Det kaldes for offerlag, da dette lag ofres for vejrlig og anden nedbrydning, og efter sin erosion vil blive fornyet, vel om 30-40 år. Selv om restaureringen af de middelalderlige ruiner også foretages af et restaureringshold i Kulturarvsstyrelsen, så er metoderne anderledes nænsomme, end når det gælder de store stengrave.

Restaureringen af Koldinghus i 1972-94 ved arkitekterne Inger og Johannes Exner er et godt eksempel på en meget vellykket restaurering, hvor forskellen mellem gammelt og nyt klart ses i en moderne æstetisk ramme. Denne skelnen i restaurering mellem originalt og nyt er ikke af ny dato. Da den italienske arkitekt og arkæolog Guiseppe Valadier i 1824 gennemførte en nedtagning og fuldstændig rekonstruktion af Titusbuen i Rom, blev dette princip anvendt, måske for første gang. Materialet til triumfbuen var oprindelig travertin be- 
klædt med marmor, men ved genopførelsen blev de manglende dele udført i samme materiale, men uden marmor for at markere forskellen.

Når Nationalmuseet restaurerer kirkernes kalkmalerier, så ser man bagefter kun de fra tilblivelsen originale dele af malerierne. Manglende partier af billederne er pudset eller kalket hvide. Skulle den samme ånd, som ved restaureringen af de store stengrave, gøre sig gældende, ville man male malerierne helt op, og så markere det nye med et diskret anbragt mærke!

Både ved restaureringen af de middelalderlige ruiner og kalkmalerierne modstår man - eller overhører - tidens krav om formidling. Her er det monumenternes bevaring og beskyttelse, der kommer i første række sammen med en vederhæftig og sober formidling på monumenternes kulturhistoriske betingelser. Den ægte vare så at sige. Sådan burde det også entydigt være for jættestuernes vedkommende. Kun omkring 600 jættestuer er fredede, og de er bevaret i vidt forskellig tilstand, lige fra de helt intakte til de næsten helt ødelagte, hvor kun stumperne af et par sprængte sten titter op af græstørven. Velsagtens 100 af de bedst bevarede jættestuer er arkæologisk undersøgt og restaureret og sikres ved løbende vedligeholdelse. De ligger jævnt fordelt over landet, så der sjældent er mere end en times kørsel til en seværdig jættestue. Derfor er der ikke af formidlingsmæssige grunde behov for at åbne flere jættestuer op for publikum og dermed heller ikke for nye gennemgribende restaureringer.

Men hvordan er det kommet så vidt? Hvorfor er der ikke for længst rejst en gennemtrængende, højrøstet kritik af den måde, som restaureringerne af de store stengrave i dag foregår på og den specielle danske håndtering af bestemmelserne i Venezia-charteret. I Kuml-artiklen fra 2008 forsvarer restaureringsholdet sig med, at konflikten med Venezia-charterets bestemmelser i 1990'erne blev "beskrevet og præsenteret i kollegiale forsamlinger i både ind- og udland, ligesom den i 1995 blev fremlagt for det daværende Kulturhistorisk Råd, som var rådgivende organ for Skov- og Naturstyrelsen [som restaureringerne dengang sorterede under]. Ingen steder var der modstand mod restaureringsmetoden, idet den skønnedes bevaringsmæssig optimal".

Det lyder jo meget tilforladeligt, men det skal ses i lyset af, at restaureringsholdet dengang i 1990'erne bedyrede, at de generelt var meget forsigtige, gravede i gamle huller, og at højest et par procent af højmassen blev berørt, ligesom man overvejende arbejdede med tidligere restaurerede jættestuer. Siden er forsigtigheden kastet over bord, og brugen af nye sten er eskaleret ofte med tilførelse af flere nye dæk- og bæresten, ikke tidligere restaurerede jættestuer bliver inddraget, der bliver også gravet i områderne foran indgangene osv. osv. 
Da der så var planer om i 2010 at foretage en større restaurering/nybyggeri af Tustrup-jættestuen ved at lægge manglende dæksten over kammer og gang og herpå jord og rullegræs, så det kunne blive en "pæn" jættestuehøj, blev det for meget for os og mange andre. Tustrup er et verdensberømt fortidsmindeområde, som ikke ligger gemt af vejen som Mogenstrup og Thorshøj, men tværtimod har stor national og international bevågenhed. Et udstillingsvindue for dansk megalitisk arkitektur. Heldigvis var Kulturarvsstyrelsen lydhør overfor indvendinger mod planen, som blev taget af bordet $-\mathrm{i}$ hvert fald indtil videre.

Dertil kommer, at når den danske stat har underskrevet Venezia-charteret, så kan/bør de enkelte landes forvaltninger ikke senere gradbøje dets bestemmelser, som de har lyst til. Det er på høje tid at få reguleret restaureringspraksis ved de store stengrave, så også vore efterkommere stadig kan opleve, hvordan en dansk jættestue tager sig ud efter 5000 år på godt og ondt og uden utidig restaurering. En mere ydmyg og mindre entreprenørmæssig holdning er tiltrængt. Lad os bruge den indvundne erfaring og de nye metoder til at vedligeholde de fredede fortidsminder på deres betingelser og i overensstemmelse med Venezia-charteret fra 1964 med dets udmærkede og brugbare bestemmelser for bevarelse af de kulturhistoriske monumenter.

I Kulturarvsstyrelsens nyhedsbrev af 1. juni 2010 meddeles, at en ny enhed "Bevaring" vil blive oprettet. Enheden skal bl.a. varetage administrationen af de fredede fortidsminder, herunder restaureringer. Det ville være et kvalitativt løft for "Bevaring", om den også omfattede et råd, der skulle vurdere, diskutere og sanktionere forslag til kommende restaureringer. I rådet skulle udover medarbejdere fra Kulturarvsstyrelsen også sidde repræsentanter fra universiteterne og museerne. Herved ville man undgå den nuværende uheldige situation, hvor Kulturarvsstyrelsen ene og alene godkender egne forslag til restaureringer. 